\title{
THE PROCESS OF TRANSFORMATION IN THE SQUATTING FACT: \\ EXAMPLES OF SANAYI AND YESILCE QUARTERS IN ISTANBUL
}

\section{A B S T R A C T}

The aim of this study is to present the process by means of which squatter settlements emerged parallel to the process of industrialization, analyze the way the squatter settlements were gradually transformed pursuant to the laws, and to discuss squatter settlements that became as areas that have recently been included in the agenda of "urban transformation projects" of the recent Istanbul's Strategic Plan. The squatter settlement selected for discussion in this study was the one that originally developed around an industrial area and later changed considerably as a result of "Urban Improvement Plans". Today, the same area has become one of the most important Central Business Areas of Istanbul, thus occupying high-priced real estate. 


\section{INTRODUCTION}

In Turkey, the migration from the rural to the urban areas occurred after the end of the Second World War as a result of industrialization development policies and implementation of mechanization in agriculture (Gürel , 2001). The unemployment resulting from mechanization implemented in agriculture helped speed up the migration towards the cities, while the existence of an industrial sector in the cities themselves acted as a magnet for those looking for employment.

The squatter phenomenon that emerged in Turkey parallel to industrialization, increased in speed over the time. People who migrated from the rural to the urban areas in the period of 1950-60 generally chose the locations near the industrial areas and built their shanties on the public land. This phenomenon was also perceived in the rest of the world beginning in the 1960's, and was defined by John F. Turner as "Freedom To Build."

In the 1950's there were around 80 thousand shanties in Turkey; this number rose to 249 thousand by the early 1960's, and by the early 1970's reached 600 thousand. Nowadays 12 million people live in around 2.5 million squatter houses, or in other words thirty percent of the urban population lives in squatter houses (Keleş, 2003).

Initially, the construction of a squatter home was a solution used by people who were not financially able to solve their housing needs and thus these squatter settlements were the result of extraordinary circumstances. In other words, building the squatter home was the first condition for those people who wanted - or needed - to live in a city. Later on this housing need turned into an impetus to gain wealth by grabbing land for speculative purposes (Dale and McLaughlin, 1999).

There are great differences between the first squatter settlements in Turkey and the situation existing today. These squatter settlements underwent their first big transformation with the amnesties in favor of illegal construction and the "Urban Improvement Plans" of the 1980's. However, as a result of this transformation, squatter construction lost its original character and became a way to gain a part of the real estate wealth of the city.

In the recent years, it has been perceived that the activities aiming at transforming the squatter settlements of Turkey were carried out under the 
umbrella of urban transformation. Squatter settlements have been defined as the areas of urban decay, and as such are included in urban transformation areas.

Beginning as of the 1990's, urban transformation efforts carried out in Turkey have mirrored such efforts taken in the west, as implementations have been directed towards revitalization of the city centers, restructuring the historic texture and improving the areas of decay.

When the cities were forced to restructure themselves because of the new international relations and were faced with inadequacies in reorganization reforms, planning, infrastructure, urban administration, organization, and physical environments (Görgülü, 2006), the "urban transformation" became a tool for intervention in problem areas of the cities.

Urban transformation is defined as a "wide-ranging vision with subsequent action for the solution of urban problems and for the lasting improvement of the economic, physical, social and environmental conditions of an area that has changed" (Thomas, 2003). The main objectives of this transformation are: arresting the physical decay of cities and ensuring the sustainability of the historic texture of a city, revitalizing economic life, promoting the quality of life of a city, serving as a catalyst for culture based dynamics and ensuring participation at every level.

While urban transformation carried out towards these objectives in the western countries tends to be of more "qualitative" nature, in Turkish implementations "quantitative" transformation gets the upper hand. Transformations in squatter settlements in particular tend to "increase the construction rights concerning an area," rather than solving social, cultural and economic conditions.

The most important characteristic of all urban transformation projects applied to the squatter settlements of Turkey following 1990 is provided by the criteria used for the selection of the areas in which to build. These areas have generally been places near the city centers and of high real estate values. Squatter settlements in central areas, with their fast increasing land values, attract the attention of the private sector and quickly become the object of transformation plans. Local administrations also try to make transformation attractive for the private sector. The kind of strategy that provides speculative profit to the private sector can also be seen in western cities. These processes run parallel to globalization, the application of neo-liberal policies and the government 
wishing to share the public sphere with some private actors, and, as a result, the logic of the private sector and the profit begin to dominate the urban transformation process (Soja, 1996).

This kind of transformation, based on the objective to make profit from the urban real estate, does not solve the problems of the people living in that area, since it does not take the social, economic and cultural environments into consideration. The questions concerning the degree to which local people have participated in transformation projects that have been carried out, the groups that have actually benefited socially from the transformation, the desired nature of urban transformation, and what could have been realized qualitatively and globally on an upper scale, remain without an answer in general.

One of the most important problems concerning the transformations applied to squatter settlements is the fact that most have yet to be formulated with a concrete organizational and financing model. Since transformation has no model incorporating the organizational and financial institutions and since it has not yet settled from a conceptual point of view, there is no real questioning of the objectives of transformation, the process by which it will be carried out, its action plan, or its social and economic effects, etc. Just as in the case of the "Urban Improvement Plans", its new model has also failed in solving the social and economic problems of the areas it has been attempting to reform. The result again becomes the increase in population density and the objective becomes quantitative - rather than qualitative - change.

\section{Problem Statement and Research Method}

This project aims at discussing the success of improvement plans for squatter settlements and urban regeneration projects in terms of creation of the qualified settlements and solving social and economic problems in those areas. To this effect, the research results gathered from a survey in the selected district in Istanbul will be evaluated. The study of the research findings will direct the research to the points that should be taken into consideration in the process of the selected sites transformation.

The squatter settlement selected for discussion within the context of this study was one that originally developed around an industrial area but later on changed considerably as a result of "urban improvement plans". Today this same area has become one of the most important Central Business Areas of 
Istanbul and thus is occupied by a high-priced real estate. The area has been included in an urban transformation area program. The essence of the transformation targeted in this area is to evict industries and substitute them with zones reserved for the services, cultural activities, commerce and recreation, while at the same time improving the residential buildings and rebuilding the social and technical infrastructure.

The method of investigation will be based on the survey and scanning written sources. Public survey, dialogue and observation were all used for the sample survey. Surveys were sited in the housing zone by using 7 percent of random sampling. The surveys sited in the housing zones consists of the questions that would reveal the data about the number of family members, where these families came from, level of education and income, number of employees, landlordism and so on. In the surveys sited for industry and trade 3 percent of random sampling were used and siting of these surveys aims at answering the questions such as whether the laborers live in these places or not and also the issues of diversity of industry and trade and workplace ownership/ relationship among the inhabitants of the district. Moreover, in order to obtain the information about the population, infrastructure and housing the neighborhood units were interviewed and in order to obtain the documents about the development of the districts, the municipalities were interviewed. The perceptions in the district provided the information on the public equipment, green spaces and the environment

\section{THE SQUATTER HOUSING PHENOMEN IN ISTANBUL AND ITS RELATION TO INDUSTRY}

The rapid development of industrialization had a direct influence upon the process of the emergence of squatter settlements. Out of the migration within Turkey in the period 1960-65, 36 percent was towards Istanbul, and in the period $1965-70$ this percentage amounted to 22 . While there were 78 thousand squatter homes in Istanbul in 1962, by 1972 this number rose to 195 thousand. In those years more than forty percent of the urban dwellers of Istanbul lived in squatter homes.

Urban population increased by $7 \%$ during those years, as a result of which thousands of squatter homes were added to the urban tissue by the workers flocking to the industrial jobs in the cities. One of the major reasons making this possible was the land reform laws that were enacted during this time. With these laws vineyards and vegetable gardens that had been owned by 
religious foundations were distributed to peasants as part of the land distribution policy. This was a major factor facilitating the transfer of the public land into the private property and even the illegal occupation of such land. Pursuant to the Law number 4753 regarding, 'Distribution of Land to the Farmers' enacted in 1945, the farmers with little or no land would be granted land and be assisted in becoming a productive family agricultural venture according to the fixed norms. During this period, those areas of Istanbul that were classified as rural were also subject to the same policy, and as time went by those lands turned into squatter settlement (www.khgm.gov.tr).

The emergence of squatter settlements

and their development:

A 'squatter house' can be described as a residential unit built in a hurry, with no sanitary facilities and with no plan, on someone else's property, and without respecting the development plans. This phenomenon is the indirect result of migration from the rural to the urban areas and of the social and economic development level of the country in which the phenomenon emerged.

In Turkey, the migration from the rural to the urban areas began in the 1940's - 50's parallel to the mechanization of agriculture. Since big cities did not possess the infrastructure to cope with such an influx of people, disorganized squatter settlements emerged in the areas surrounding cities. All these squatter settlements developed in relation to industrial areas. In other words, the squatter settlements emerged in the environs of the industrial areas. The rapid development of industrialization had a direct effect upon the process by means of which squatter settlement emerged. The first shanties emerged on property belonging to the Public Treasury and were built by the very hands of the migrants themselves. The most important characteristic of the squatter house of this period was that they were built by the people who would live in them thereafter.

During the process of formation of squatter settlements, the government, until the end of the 1950 's, took a passive stance and preferred to make only small interventions related to the short-term problems within the city, rather than trying to prevent or solve bigger problems.

The government officially recognized this problem for the first time with the Squatter House Law number 775, enacted in 1965. This law that defined the squatter house and tried to introduce measures to solve the problem on the basis of the principles specified by the development plans has been in effect 
even today. During this period, squatter houses were periodically demolished and Public Treasury owned land was transferred to the city administrations, with the aim of preventing the construction of shanties on it.

By the 1970's the commercialization of the squatter settlement began. First of all, the method of appropriation of empty lots changed. While during the first period shanties were built by occupying Public Treasury-owned land, beginning from this period, the builders of squatter houses started to obtain their lands by buying it from the private owners. The owners of vast tracts of land around the city began subdividing their holdings into lots and selling them. By then 'shanties' began to be built not with the aim of being lived in by the builder, but of being sold or rented, and by then many people owned more than one residential unit. In this way houses rented by their residents began to emerge. During this period, the owners of these squatter houses began to add new stories on top of the existing houses, or they would demolish the existing houses and build the apartment blocks in their place, for speculative purposes. What changed was not just the way the lots were acquired, but also the way the squatter houses were built. With an increasing volume, these buildings began to be built by people other than those who were going to live in them, and thus a new construction sector was created.

In addition to these changes, the amnesties granted to illegally built buildings also contributed to the transformation of the single-storey shanties into multi-storey apartment blocks. By means of these amnesties, illegal and disorderly building was in a way regulated, and the property titles of certain areas were distributed, with certain limits, to those using the dwellings. With the consecutive amnesties in the second half of the 1980's, all such shanties disappeared. First, the single-storey squatter houses in the areas near the city center were demolished and multi-storey apartment blocks were built in their places. These amnesties created a series of variations between the former squatter settlements. On the one hand, there were areas in relatively favorable locations within the city where, for speculative reasons, squatter dwellings were turned into apartment blocks resulting in the increase in building density, inadequacy of infrastructure, and low environmental standards; on the other hand, there were also areas that did not enjoy such prime location. In these areas the transformation of the buildings was carried out by the dwellers themselves with their own means. The buildings in this second type of areas were far from satisfying the needs of the dwellers, and the areas themselves quickly turned into areas of decay. These areas differed both in their physical environmental characteristics and in the profiles of their inhabitants (Işık, Pınarcıoğlu,2001). 
The biggest transformation that the squatter settlement phenomenon has undergone consists in the fact that while in its early days a dwelling unit was built for its usage value, nowadays the present day equivalent is built for its exchange value. Another change is that contrary to what happened earlier, building of these structures is not carried out by a single actor; in other words the person occupying the land, building the structure and using it is no longer the same individual. The squatter house has stopped being just a dwelling unit and has turned into a phenomenon that facilitates speculative participation in the city's real estate wealth.

In the 1980's this transformation process of squatter settlements gained in speed. The most important factor here is that, because cities expanded very fast, the cities ended up surrounding those squatter settlements that had been located outside city limits back when they were first built. This change in the size of the cities themselves greatly increased the value of the land in the squatter settlements. As a result of this increase in land values, shanty owners either demolished their shanties, building illegal apartment blocks in their place, or added new sections to the existing buildings for rental purposes, thus making an extra income.

Together with these changes, the squatter houses also changed qualitatively. When the first squatter houses were built, the aim of their owners was to use whatever materials they found at hand to put together a dwelling unit rather quickly. As building technology progressed and income rose, more durable materials like bricks and concrete began to be used. The Increase in land values brought about the construction of apartment blocks, and also renewal and a tendency to get closer to city standards in what were formerly squatter settlements (Görgülü,1997).

\section{The chronological history of Istanbul's industrial plans:}

Development plans were introduced in Istanbul during the first years of the Republic when population began to grow. The most important aspect of the plan formulated by Henri Prost in 1937 was that that major industry would be located on the shores of the Golden Horn. According to this plan, the area between the Horn's Atatürk Bridge and the source of the Golden Horn would be reserved for major industry, while the older neighborhoods between the Galata and the Atatürk bridges would be the centers for wholesale vegetable and fish markets and other food wholesalers. 
Following the establishment of the Golden Horn area as an industrial area by the Prost Plan, in 1947 the Istanbul Mayoralty Construction Directorate prepared the 'Regulation Concerning the Industrial Areas of Istanbul,' and in 1949 the corresponding commission prepared a report. According to this regulation, the Eyüp-Silahtarağa, Eyüp-Edirnekapı and Yedikule-Bakırköy areas were to be used for heavy industry, while the two sides of the Golden Horn were reserved for medium sized industrial establishments. The 1949 report added the northern part of Eyüp, the area around Maltepe, Kazlıçeşme, Zeytinburnu, the outer parts of Bakırköy, Yeşilköy and Küçükçekmece on the European side, while on the Anatolian side the areas added as industrial areas were the Maltepe-Kartal surroundings, Pendik, and Kadıköy as areas reserved for heavy industry.

During these same years, people immigrating to Istanbul began to settle in areas surrounding the industrial areas. Kağıthane and Zeytinburnu emerged as the first squatter districts. While in 1951 there were 8500 shanties in the whole city, by 1957 there were 26 thousand shanties in the Zeytinburnu district alone. Following this district, the second big neighborhood of squatter housing, known as Taşlitarla, emerged near the Eyüp-Rami industrial area.

The industrial plan prepared in 1954 by the Consultants' Council declared the areas between Mecidiyeköy-Levent, Mecidiyeköy-Şişli-Bomonti and Kasımpaşa-Kağıthane on the European side to be industrial areas. The Istanbul Industrial Plan introduced in 1955 suspended industrial development along the Golden Horn, with the result that the new industrial areas were established in Topkapı-Rami and in Levent (Tümertekin,1972). The fact that these plans did not have provisions related to the increases in population and to eventual responses to these increases encouraged the construction of squatter housing around these areas.

In the 1950's Kağıthane became the biggest squatter settlement following Zeytinburnu and Taşlitarla. On the Anatolian side unregulated areas like Maltepe and Kartal saw the formation of new such squatter districts.

The point made in the 1966 industrial zoning plan was that industry should be planned first at the level of the Eastern Marmara and Thrace Areas and only following that within Istanbul's metropolitan limits (Zaimoğlu, 1971). This plan required the creation of Organized Industrial Areas with the aim of encouraging industrialization. The assumption of the plan was that the city would develop towards the east rather than towards the west, and the aims 
set on this basis were a 'controlled' decentralization within regional and metropolitan boundaries, the development of infrastructure in this direction, and the transformation of Istanbul's metropolitan structure by means of creation of Organized Industrial Areas (Giritlioğlu, Yüzer, Yüzer Ş,1998) (Table 1).

As for the Istanbul Metropolitan Area Zoning Plan approved in 1980, the policy concerning the industrial sector would be characterized by the following elements:

- Ensuring a balance in the distribution of metropolitan employment areas,

- Relocating the industry away from the center of the metropolis,

- Regulating and utilizing industrial trends,

- Preventing polluting industries from being established in the metropolitan area,

- Using public authority to induce industry to prevent pollution by technological means.

Other points stressed in the plan were to encourage, within the framework of the plan, the establishment of high technology and know-how based industries within Istanbul proper, and to relocate the industries that use standard technologies and large supplies of water and/or energy out of Istanbul (BINPB, 1980).

Approved in 1995, the 1/50000 scale Istanbul Metropolitan Area Zoning Plan for Sub-Districts was aimed at cleaning up, transformation and decentralization of the industrial areas. Tuzla, Maltepe, Kartal and Pendik on the Anatolian

\begin{tabular}{|l|l|l|l|}
\hline \hline Area & $\begin{array}{l}\text { Available area } \\
\text { (ha) }\end{array}$ & $\begin{array}{l}\text { Vacant area } \\
\text { (ha) }\end{array}$ & $\begin{array}{l}\text { Total industrial area } \\
\text { (ha) }\end{array}$ \\
\hline \hline Rami industrial area & 43.50 & 167.00 & 210.50 \\
\hline Topkapı industrial area & 58.30 & 147.00 & 207.30 \\
\hline Halkalı industrial area & 43.90 & 225.00 & 268.90 \\
\hline Levent industrial area & 13.00 & 37.00 & 50.00 \\
\hline Bomonti industrial area & 6.60 & 15.00 & 21.60 \\
\hline $\begin{array}{l}\text { Levent car repair } \\
\text { workshop area }\end{array}$ & 4.70 & 4.50 & 9.20 \\
\hline Kurtköy & - & 285.00 & 285.00 \\
\hline Ümraniye & - & 63.00 & 63.00 \\
\hline Total area & 170.00 & 885.00 & 1140.50 \\
\hline
\end{tabular}




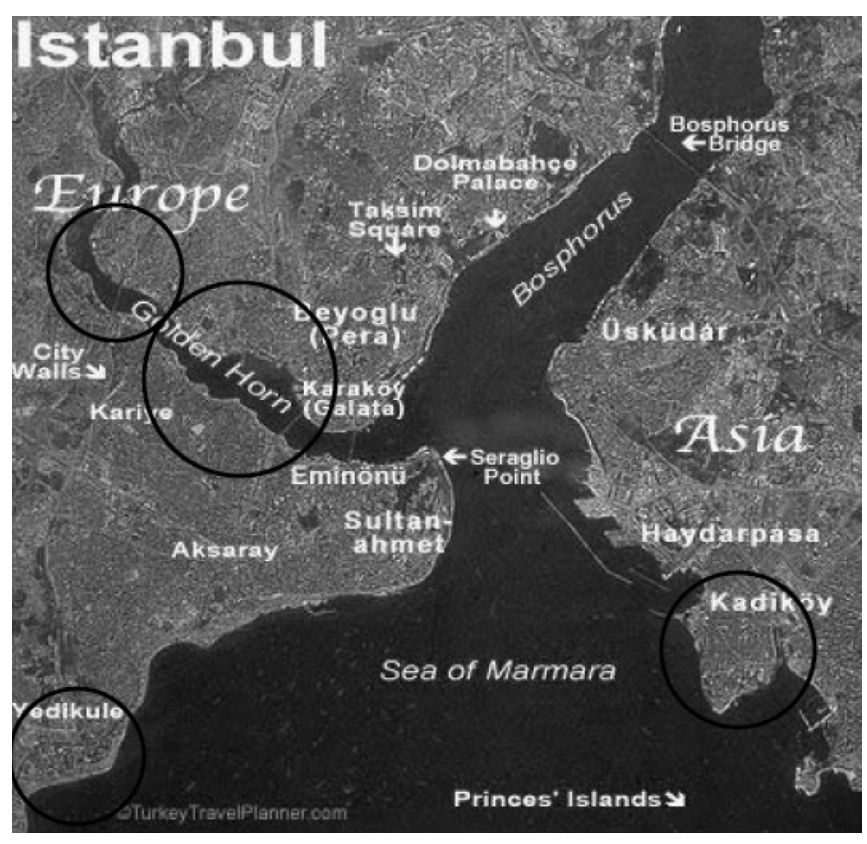

Figure 1

First Industrial areas in İstanbul (www.zemin6.com)

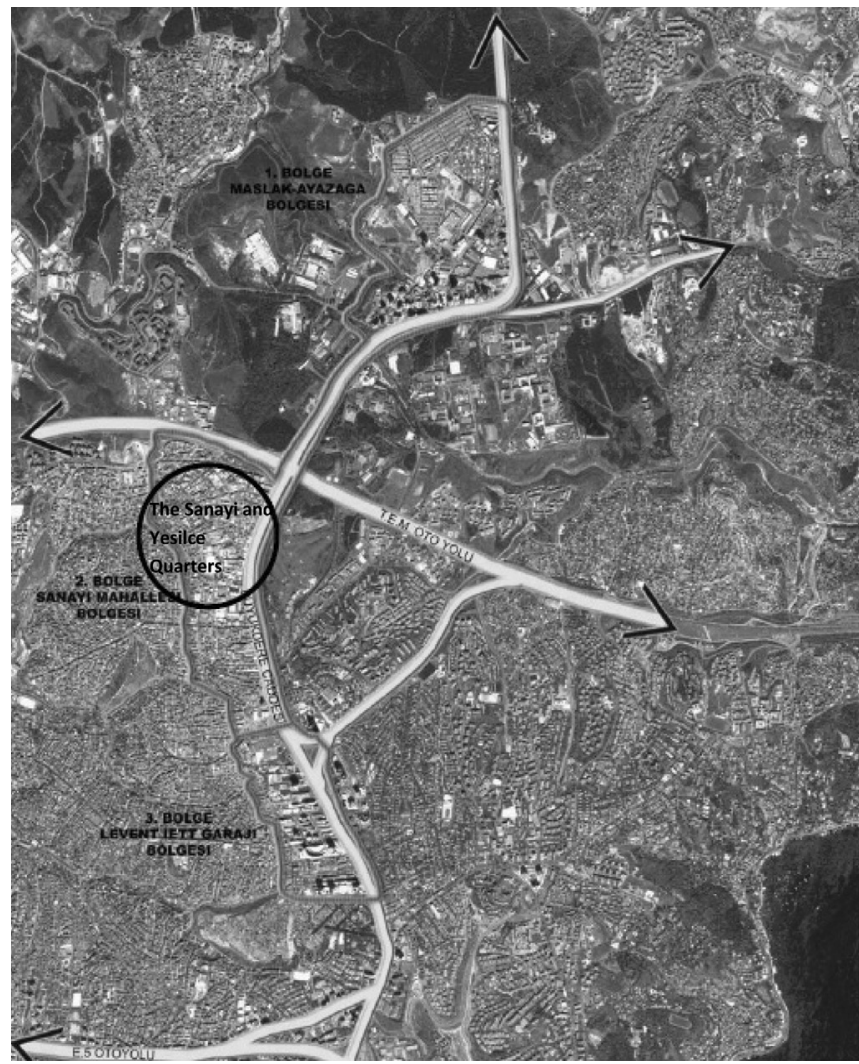

Figure 2

Sanayi and Yeşilce Quarters in Levent - Maslak Central Business District 
side of the city and Bakırköy, Bayrampaşa and Zeytinburnu on the European side were designated as areas that must be transformed from industrial to service sector areas. Another aim was to convert the decayed urban areas into Central Business Areas that would serve the Istanbul metropolitan area.

The aim of this plan was to develop two major Organized Industrial Areas that would bring small and mid-size industries into planned areas (Istanbul Metropolitan Area Sub-area Level Zoning Plan Report, 1995).

- The İkitelli Organized Small Industry Area was created as the site which all production activities being carried out in the Historic Peninsula of Istanbul would be transferred to;

- The Tuzla Organized Leather Industry Area, on the other hand, was created on a 642 hectare area as a new decentralized location for the leather industry formerly located at Kazlıçeşme.

This plan established the new industrial areas for a total of 2901 hectares on the European side of Istanbul and a total of 1791 hectares on the Asian side. Other industry and some fields of small industry were distributed to various areas of the city, with the aim of creating specialization.

The industrialization process of Istanbul brought along a completely new phenomenon: "The emergence of squatter settlements."

Planning processes aiming at changing squatter settlements

The first renewal transformation of Turkey's squatter settlement occurred in the 1980's with the "Urban Improvement Plans." The aim of these plans was to demolish the squatter dwellings so as to be able to erect new buildings in their place, provide infrastructure to these areas and subdivide them into lots. As a result of this, the owners of squatter houses were given "Title deeds" that were supposed to form the basis of the actual property deeds after the implementation of the reform.

However, new problems were encountered while attempts were being made to transform squatter settlements by means of "Urban Improvement Plans" because these areas were planned according to low standards, and because the increase in the building possibilities related to these deeds brought about the result that this transformation was carried out according to market rules. The main problems were: 
- Transformation did not create the hoped for physical environment,

- While population density increased, services like education, health, green areas, roads and parking spaces remained at very low standard levels,

- Transformation did not bring about fairness or an improvement in socio-economic conditions,

- The main results were the transformation of squatter dwellers into property owners, the legalization of illegal buildings, and the provision of speculative gains to the owners of illegal buildings, rather than reforming these areas.

As for the situation nowadays, the local authorities, recognizing that the "Urban Improvement Plans" had proven ineffective, are trying to change the nature of squatter settlements by using "urban transformation projects." In this context, the Turkish Ministry of Public Works has relatively recently issued an "Urban Regeneration Bid in the Parliament" to ensure the transformation from squatter and illegal buildings, to an orderly urban structure. According to the, "Urban Regeneration Bid in the Parliament", the aim of which is not just to solve the problems of squatter settlements, but also to ensure that all buildings are earthquake-resistant, the following areas will be subject to transformation:

- The areas in a rural or an urban setting that have been partially or totally built over or that are being built over, and that are subject to the risk of natural or technological disasters, or to urban dangers and risks,

- The sites that have decayed from a social, economic or physical point of view,

- The areas in which the natural, historical, cultural environment or the ecosystem need to be conserved, preserved, and developed,

- The sites with inadequate and/or low quality social and technical infrastructures.

Certain programs that were termed "transformation" were also implemented in various squatter settlements before the Urban Regeneration Bid in the Parliament. The problems resulting from such programs were similar to the problems encountered as "a result of the introduction of Urban Improvement Plans".

Consequently, it can be stated that, contrary to the urban transformation experience in the west, Turkey's urban transformation aimed at a quantitative change of a speculative nature and did not take into consideration the economic, social, physical-environmental and organizational aspects of the process. 
The following part of this study will consist of the results of polls and researches carried out in the Sanayi and Yeşilce neighborhoods, which can be taken as the examples of squatter settlements that had emerged as a result of the above-mentioned processes and that were transformed by "Urban Improvement Plans".

These two neighborhoods were established outside city limits with connections to industrial areas, but nowadays find themselves located within Istanbul's most important central business area axis, or in other words in an area with the potential for speculative profits, and have been included once more within the scope of an urban transformation area. The aim of this study is to analyze the physical changes undergone over time by both neighborhoods and, by presenting its present problems, to initiate a debate of the points to be taken into consideration during the process of transformation.

\section{THE SANAYI AND YESILCE QUARTERS}

These neighborhoods located on the Zincirlikuyu-Maslak axis, which is Istanbul's most important central business area, were established around the year 1955 on Public Treasury and city property. The industrial plan prepared during those same years by the Commission for the Reconstruction of the City, established the new industrial areas in Levent and this led industry to expand towards Büyükdere Avenue. Since the value of these areas reserved for industry increased very fast, the investors preferred areas that were not controlled and had relatively low values. When public lands surrounding these areas were used by speculators, these lands that had at that time a rural landscape, began to be built over in an unplanned way as a result of industry, and consequently many squatter settlements emerged.

Like other neighborhoods in those parts, the Sanayi and Yeşilce neighborhoods were also the areas outside city limits with a rural status, administratively speaking.

\section{Development of the Levent Automobile Site}

The area that nowadays is the Automobile Industry Site emerged when in 1954 the Commission for the Reconstruction of the City determined that the Mecidiyeköy-Levent axis was to be reserved for industry. The old name of this site that was established in 1966 with a partial development plan with the scale of 1/5000, was the "Limited Responsibility Istanbul Automobile Industry District and Vehicle Trading Cooperative.” In 1974 this area was changed 


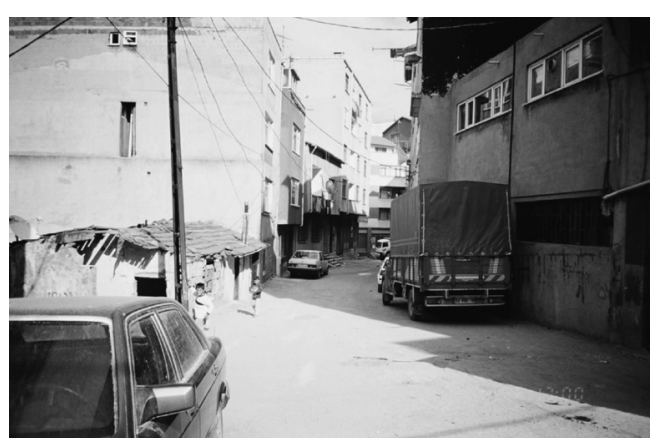

Figure 3

View of The Sanayi Quarter

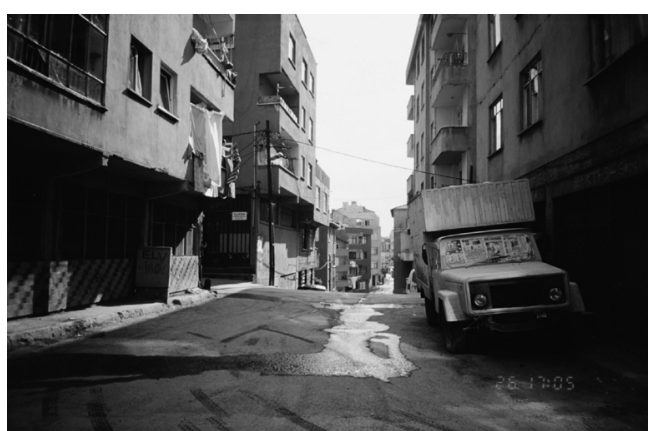

Figure 4

View of The Sanayi Quarter

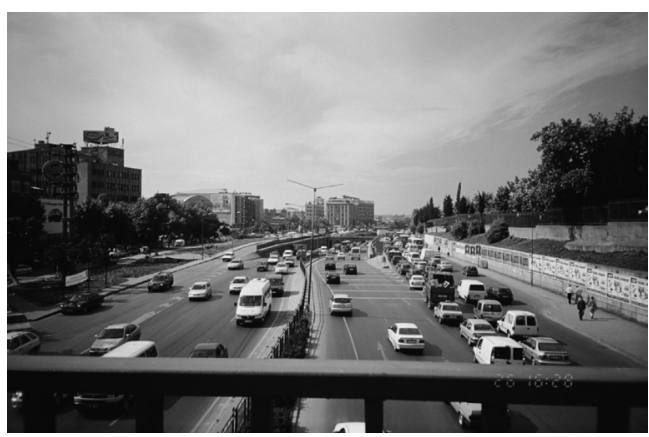

Figure 5

View of Zincirlikuyu - Maslak axis 
according to new requirements and by completing the plan, and its new name became "Limited Responsibility Levent Automobile Industry Cooperative."

Around 170 workshops were set up in the automobile industry site; later on, as a result of subdivisions, they increased in number. About 1000 people have been employed in this location.

\section{THE PRESENT DAY SITUATION OF THE SANAYI AND YESILCE NEIGHBORHOODS}

The survey findings concerning the housing and the industrial zones are discussed below.

Locati on: The Sanayi and Yeşilce neighborhoods are part of the Kağıthane Municipality, and are located on the Zincirlikuyu-Maslak axis, which is Istanbul's most important central business area. These neighborhoods also began to develop as a result of the Law number 4753 for the 'Distribution of Land to the Farmers,' enacted in 1945. Until 1987 these neighborhoods retained their official status as rural villages within Kağıthane.

In 1987 the legal status of Kağıthane was changed from that of a village within the Şişli Municipality administrative limits to become a separate mayoralty itself independent from Şişli; this in turn engendered the emergence of many new neighborhoods within Kağıthane.

Socio-cultural structures: The data concerning the socio-cultural structure and the nature of residential units, obtained by house-to-house polls carried out in both neighborhoods, are as follows:

In the Sanayi neighborhood, which is settled by people who migrated to Istanbul from Anatolian cities like Gümüşhane, Sivas, or Bayburt, the families consist of at least five members. During the last ten years this neighborhood received an influx of people from Turkey's south-eastern areas. These people make up $3 \%$ of the total population.

Even though the number of children per family is at least 3, it has been noticed that in this neighborhood there are also families with 8-9 children. Fifteen percent of dwellers here own their homes, while thirty percent own vehicles. 
The house ownership percentage of the Yeşilce neighborhood is $30 \%$. Both neighborhoods are inhabited by people loyal to their religious traditions, and both neighborhoods resemble typical Muslim neighborhoods.

The education level in these neighborhoods is rather low and the majority consists of people who have completed only their elementary school education. The rate of literacy is $80 \%$. Of those employed, $90 \%$ are blue-collar workers, while $10 \%$ are white-collar employees. Workers generally work on construction sites and in the garment industry. These neighborhoods are characterized by a generally young population and the biggest problem is the unemployment. In the Sanayi neighborhood, unemployment among the young is as high as $70 \%$. The general income level is also low, and most of the population work at the minimum wage. A great majority do not have social or health insurance. In the Sanayi neighborhood, those with a high-income level make up $10 \%$ of the total population. This group is generally made up of those who first migrated to the neighborhood and who made speculative profits by turning their original squatter dwellings into apartment buildings. In the Yeşilce neighborhood there is no equivalent category.

Those who work in the furniture, garment, woodworking and repair workshops scattered among the houses increase the population of the neighborhood during the day. The percentage of people of this neighborhood who work in the Levent Automobile industry site - the socio-cultural level of which is rather low--has decreased in comparison to previous years, but nevertheless $15 \%$ of all employed people in the neighborhood still work there.

The population of the Yeşilce neighborhood is made up mostly of people who have migrated from Sivas, Kastamonu and the Black Sea area. The Yeşilce neighborhood is similar to the Sanayi neighborhood from the socio-cultural and economic point of views. From the point of view of the number of children, the families are smaller than those at the Sanayi neighborhood. The fact that the number of working population is 5000 shows that the Yeşilce neighborhood basically serves as the dormitory for the workers.

Another noteworthy characteristic of these two neighborhoods is the existence of close bonds among the people who have come from the same areas of Turkey. During the interviews it was observed that many people in these neighborhoods are related to each other, or at least know each other very well, and that in general human relations are as close as they would be in a village. This web of relations complicates things when there are conflicts with the 
public authorities, and because the crime rate is high, such situations occur very frequently. It has been observed that incidences of theft and purse snatching have increased in the Sanayi neighborhood during these last few years.

Another important finding concerns the fact that especially in the Sanayi neighborhood children very frequently have health problems. This is thought to be due to the nutritional and life standards of the people living on the border of poverty.

Population and the nature of residential units: In 2005 the population of the Sanayi neighborhood was 52.000, while that one of the Yeşilce neighborhood was around 18.000 (the offices of the head-men of the Sanayi and Yeşilce neighborhoods).

The Sanayi neighborhood was established as a squatter settlement, but as of 1986 the squatter dwellings were replaced by multi-storey buildings. The main reasons for this were that when the "property deed assignation documents" were distributed, the original dwellings were demolished and 5-6 storey buildings were built in their place, and the fact that since this neighborhood is close to the city center it acted as a magnet for the low-income classes.

In this neighborhood there are approximately 8500 residential units, having the areas ranging between 70 and 110 square meters. Most of the buildings in this neighborhood are without permits and most are below norms and standards from the points of view of construction techniques, ease of utilization and hygiene. In a neighborhood made up of such buildings one cannot speak of environmental or living quality. Notwithstanding all unfavorable circumstances, the prices of apartments in this neighborhood in 2006 ranged between 70 and 150 thousand liras. As for the rents, they varied between 400 and 750 liras per month.

As for the Yeşilce neighborhood, it separated off from the Sanayi neighborhood and acquired its own features. Within its borders there are garment making, car painting, and car repair workshops and warehousing areas. All this is an unplanned adjunct expansion towards the south of the planned automobile industry site, and makes up most of the neighborhood. The population of this neighborhood numbers 18,000 and is mostly made up of people coming from the city of Sivas. The number of workers is around 5000 people. As in the case of the Sanayi neighborhood, buildings have changed. In this neighborhood, made up of multi-storey buildings, there are about 5700 residential units. Prices and rents are similar to those in the Sanayi neighborhood. 
Around $60 \%$ percent of the residential units in the Sanayi neighborhood do not have property deeds, while in the Yeşilce neighborhood this percentage rises to $90 \%$.

Industry and Commerce: The main industry of the Sanayi neighborhood is the textile industry. In addition to this, there are also furniture, ironworking and other workshops. Because industrial areas have developed in an unplanned way among residential buildings, the neighborhoods are unpleasant both aesthetically and from the point of view of hygiene. The main reasons for the textile industry to have concentrated in this area are that these two neighborhoods are near the city center and that since most of their population is working-class there is an abundance of low-cost workforce.

The Sanayi neighborhood has a developed commercial axis. The rents of the shops on this axis vary between 3 and 4 thousand liras per month. The majority of the shops along this axis consist of clothing shops, small supermarkets, jewelry shops, household appliances dealers, furniture shops and restaurants. Researches carried out as regards this matter show that many of the shops on the commercial axis are owned by people living in these neighborhoods. About $60-70 \%$ of the merchants operating out of these shops are from other areas of the city.

The reasons why commerce has developed so much in the Sanayi neighborhood, even though it is inhabited by low income segments of the society, are: The area on the opposite side of the Levent -Maslak axis has a small and planned commercial area. The people living in the latter satisfy their shopping needs mostly in more upscale establishments like Metrocity, etc. Apart from these shopping needs, other services like repairs, carpentry, hardware shops, tailors, and iron working that are not available in the major shopping centers are located within the Sanayi neighborhood.

From a commercial point of view the Yeşilce neighborhood is rather developed, for it is served by the Sanayi neighborhood. Sixty percent of the buildings in this neighborhood are used for industrial purposes. The other $40 \%$ consists of residences. From this point of view the Yeşilce neighborhood is an industrial area. There are various industries like painting manufacture, textiles, car-repair shops, printing houses or cooking centers for catering services.

Social infrastructure and green areas: It is interesting to note that in the Sanayi neighborhood there are four mosques and two mescit 
(small mosques). In the Sanayi neighborhood there is one clinic, one publiclyowned hospital and one private hospital. As for the educational infrastructure there are four elementary schools, one school for the handicapped people and one high-school level school for the clerics and preachers. The great number of cyber-cafés is noteworthy.

There is only one soccer field in this neighborhood. There are no recreational green areas, parks or playgrounds. In the neighborhood there is a parking lot run by a private enterprise.

The neighborhood's most pressing need is for playgrounds. Apart from this there are not enough parking spaces and high school level educational establishments.

As for the Yeşilce neighborhood, there is absolutely no social infrastructure, including educational establishments. One of the biggest problems, just as in the case of the Sanayi neighborhood, is the lack of green areas.

Another big problem out of many in both neighborhoods, which are characterized by extremely insufficient and unhygienic infrastructure, is the fact that as a result of the increasing concentration of industry with its large consumption of electricity there are frequent power cuts. Sewerage systems are insufficient in both neighborhoods. Apart from this, the trash that is casually left here and there on the avenues and streets has a negative impact on the inhabitants, both visually and from the point of view of hygiene.

The result of this research shows that from the points of view of their general appearance, their environmental and life standards, the way that they have been built over, and their social, cultural and economic structure, the Sanayi and Yeşilce neighborhoods are just two out of the hundreds of problem ridden areas within the Istanbul metropolitan area. Even though residential buildings and industrial areas are one on top of the other in these neighborhoods, because of the unplanned industrialization and construction, these neighborhoods do offer attractive opportunities since by now they have come within city limits, and as a result of this multi-storey buildings are fast rising. The new construction activities have increased the number of residential units for rent in these areas and this has provided great opportunities for those who migrated during the last twenty years from Anatolia to Istanbul. The fact that local informal entrepreneurs transformed the single-storey buildings of the area into multistorey buildings increased the population density of these neighborhoods, 
but the informal status of these entrepreneurs has not changed. Even nowadays $50 \%$ of the owners of multi-storey buildings do not hold property deeds.

These neighborhoods did not change in social, cultural and economic perspectives with the passage of time, and being places where second or third generation industrial worker families lived they are now turning into ever poorer slums. Whereas in the past these places developed out of squatter settlements connected to industry, nowadays only a small percentage of the employed people of these neighborhoods work in the industries within the neighborhood, while the rest of them go to various other areas of Istanbul to work.

\section{RESULTS AND DISCUSSION}

The result of this research shows that Urban Improvement Plans implementations transformed these neighborhoods from settlements made up of one storey squatter dwellings into multi-storey residential buildings neighborhoods, but that those transformations were quantitative in form rather than qualitative, since they did not induce any physical, social or economic improvements in the environment.

A vision is required for these neighborhoods to be declared urban transformation areas and for policies to be implemented here that will serve purposes like finding solutions for social, economic and physical environment problems, upgrading the standard of life, and ensuring the participation of the local population. Within the context of this vision, transformation plans applied to Turkey's squatter settlements urgently require a National Strategic Action Plan and local action plans and strategies to be formulated on a local scale. The aims of these areas should be to improve the quality of residential buildings and the physical environment, improve education and its infrastructure, reduce unemployment and crime rate, and integrate these areas into the city.

The data concerning the subject of the study of the neighborhoods show that:

- the buildings of this area have changed from single-storey dwellings to poor quality, multi-storey buildings,

- the technical infrastructure, the social infrastructure, the green areas and the quality of the environment are all inadequate,

- the levels of education, culture and income are all very low,

- the levels of unemployment of these districts with the young population are high, especially so in the Sanayi neighborhood, 
- crime rates are increasing,

- the neighborhoods have kept their rural socio-cultural structure, and because of their inward-orientated life have not been able to integrate within the city,

- the Levent Automobile industry site has stopped being an important source of employment for these neighborhoods.

The physical, social, and economic dynamics and the organizational structure have to be taken into consideration if the urban transformation project to be implemented in the Sanayi and Yeşilce neighborhoods is to be successful.

The physical-environmental aspect: This is generally the basic element of physical transformation. The problems and potentials of the physical background of these projects have to be determined very carefully. Within this context, and in the case of both neighborhoods, it is necessary to improve the qualities of the buildings, improve and develop the technical infrastructure, reach acceptable standards as far as equipment and services are concerned, improve environmental quality, and ensure that the transformation does not bring about an increase in the density of residential units. The high-quality environments made up of management buildings, shopping centers and residences that have been built all along the Zincirlikuyu-Maslak axis should also be set up in these two neighborhoods that are contiguous to this axis.

The social aspect: The local population has to be made part of the transformation project and has to play a role during the process. For the various communities in the neighborhoods to be made part of the process and for a sense of ownership to develop, special needs have to be determined, groups have to be represented on equal bases and the local population has to be empowered. During all activities to be carried out within this context, the low socio-cultural level of both neighborhoods should be taken into consideration. To ensure a high quality and effective participation, the population has to be informed and enlightened, and organized and planned participation models should be created. Policies aimed at the younger generations should be developed; schools providing basic education should be established; and younger people in particular should be trained in a way to make them more employable.

The economic structure: In these neighborhoods where the unemployment rate is already very high, unemployment is expected to increase even 
more when the industrial establishments scattered in the neighborhoods are evicted. To ensure that the service, cultural and commercial facilities that are planned to replace the evacuated industrial establishments can create job opportunities for the inhabitants of the neighborhood, plans to train the local people should be supported so as to increase their employability and the financial and administrative support for the development of these neighborhoods should be provided.

Organizational structure: The key actors of the transformation process should be selected and coordinated. The local population should make the active actors in the transformation process to be implemented in these neighborhoods. The fact that the private sector might gain precedence as active actors during the transformation process of these neighborhoods that have speculative potential, is one of the main factors that might influence the social aspect of this transformation. Within this context, it has to be stated that the added value should be directed towards the benefit of the local people. Plan Bürosu Başkanlığı,1980.

Dale, Peter and McLaughlin, John D. Land Administration. New York: Oxford University Press, 1999.

Giritlioğlu, Cengiz, and Yüzer, Mehmet A. and, Yüzer, Şebnem. "The Examination of Differentiation Seen in Location of Industrial Areas in Istanbul". $38^{\text {th }}$ Congress of the European Regional Science Association, Vienna-Austria, 1998.

Gürel, Sümer. 21. Yüzyıl Karşısında Kent ve İnsan, ”“Türkiye’ de Göç ve Bütünleşme Sorunsalı”. İstanbul: Bağlam Yayınları, 2001.

Görgülü, Zekai. “Gecekonduda değişen nitelikler“. Kent Gündemi no.1 (1997):19-23.

Görgülü, Zekai. "Planlamada Bir Araç:Kentsel Dönüşüm“. Mimarlık no.322 (2006):26-27.

IBB. 1/50000 Ölçekli İstanbul Metropoliten Alan Alt Bölge Nazım Plan Raporu. Istanbul Büyükşehir Belediyesi Şehir Planlama Müdürlüğü, 1995.

ISO. İstanbul Metropoliten Alanında Sanayi Yerleşim Planlaması. Istanbul Sanayi Odası Yayınları, 1981.

Işık, Oğuz, and Pınarcıŏlu, Melih. Nöbetleşe Yoksulluk Sultanbeyli Örneği. İstanbul: İletişim Yayınları, 2001. 
Kağıthane Municipality.

Keleş, Ruşen. "Türkiyede Gecekondu Sorunu“. Mühendislikte Mimarlıkta Planlamada Ölçü Dergisi no:30 (2003):39-45

The Offices of the Head-men of the Sanayi and Yeşilce Neighborhoods.

Soja, Edward. Third Space: Journey to Los Angeles and Other Real and Imagined Places Oxford: Blackwell, 1996.

Şişli Municipality (for the car industry plan).

Thomas, Saalfeld. A glossory Of Regeneration And Local Economic Development. Manchester: Center for Local Economic Strategies, 2003.

Turner John F. C. Freedom to Build; Dweller Control of the Housing Process. New York: Mac Millan Publishing Company, 1972.

Tümertekin, Erol. İstanbul Sanayiinde Kuruluş Yeri-Analysis of the location of Industry in Istanbul. İstanbul Üniversitesi Yayını, 1972.

Zaim, Sabahaddin. Bölge ve Şehir Planlaması Yönünden İstanbul Sanayi Bölgeleri. İstanbul: Hüsnütabiat Matbaası, 1971.

www.khgm.gov.tr 